\title{
Pengaruh Prinsip-Prinsip Good Corporate Governancedan Pertumbuhan Aset pada Kinerja Keuangan
}

\author{
Ni Made Aget Luwih ${ }^{1}$ \\ Ketut Muliartha $\mathbf{R M}^{2}$
}

\author{
${ }^{1}$ Fakultas Ekonomi dan Bisnis Universitas Udayana (Unud), Bali, Indonesia \\ email :luwihderana@gmail.com/Telp.081236014224 \\ ${ }^{2}$ Fakultas Ekonomi dan Bisnis Universitas Udayana (Unud), Bali, Indonesia
}

\begin{abstract}
ABSTRAK
Penelitian ini bertujuan untuk mengetahui pengatuh prinsip - prinsip good corporate governance pada kinerja keuangan yang diukur dengan return on assets pada kinerja koperasi di Denpasar Selatan. Penelitian ini menggunakan metode pengupulan data dengan teknik kuisioner dan dokumentasi. Sampel yang digunakan sebanyak 60 sampel dari 20 koperasi amatan yang ada di Kecamatan Denpasar Selatan dan masing - masing koperasi diambil tiga responden. Metode penentuan sampel menggunakan purposive sampling. Teknik analisis yang digunakan adalah analisis regresi linier berganda dengan SPSS. Berdasarkan hasil pengujian hipotesis menunjukkan, prinsip resposisbility berpengaruh negatif terhadap kinerja keuangan koperasi, sedangkan prinsip transparency, accountability, independency, fairness serta pertumbuhan asset tidak berpengaruh signifikan pada kinerka keuangan koperasi di Kecamatan Denpasar Selatan.
\end{abstract}

Kata kunci : pertumbuhan asset, koperasi, kinerja keuangan, return on assets.

\begin{abstract}
ABTRACT
This study aims to determine the effect of the principles of good corporate governance on financial performance as measured by the return on assets of cooperatives in the District of South Denpasar. This study uses data collection methods with questionnaire and documentation techniques. The sample used was 60 samples from 20 observing cooperatives in the District of South Denpasar and each of the three cooperatives was taken. The sample determination method uses purposive sampling. The analysis technique used is multiple linear regression analysis with SPSS. Based on the results of testing the hypothesis shows, responsibility principle. negative effect on the cooperative's financial performance, while the principles of transparency, accountability, independence, fairness and asset growth have no significant effect on the cooperative's financial performance in the District of South Denpasar.

Keywords: asset growth, cooperatives, financial performance, return on assets.
\end{abstract}


Ni Made Aget Luwih dan Ketut Muliartha RM. Pengaruh...

\section{PENDAHULUAN}

Data pada Dinas Koperasi, UKM, Perindustrian dan Perdagangan kota Denpasar menyebutkan bahwa di Kecamatan Denpasar Selatan pada tahun 2017 terdapat 65 Koperasi Simpan Pinjam (KSP) dimana 62 KSP masih berstatus aktif dan sisanya berstatus tidak aktif. Seiring dengan berkembangnya koperasi ternyata masih banyak koperasi yang tidak melakukan RAT, sedangkan Rapat Anggota Tahunan (RAT) merupakan agenda wajib setiap badan usaha koperasi, karena di dalamnya akan dibahas tentang pertanggungjawaban pengurus koperasi selama satu tahun kepada anggota koperasi yang bersangkutan. Tercatat 27 koperasi tidak melaksanakan RAT pada tahun 2017 hampir setengah dari jumlah koperasi tidak melakukan RAT, hal ini mengindikasi bahwa masih kurangnya penerapan good corporate governance pada organisasi Koperasi Simpan Pinjam.

Prinsip-prinsip good corporate governance sebagaimana disusun oleh Organization for Economic Cooperation and Development (OECD) meliputi, transparansi (transparancy), akuntabilitas (accountabillity), tanggung jawab (responsibility), kemandirian (independency) dan keadilan (fairness) yang selanjutnya disingkat menjadi TARIF. Arti dari TARIF adalah sebagai berikut : (1) Transparansi (transparancy) adalah meningkatkan keterbukaan (disclosure) dari kinerja perusahaan secara teratur dan tepat waktu serta benar. Dalam pengambilan keputusan, direksi dan dewan komisaris senantiasa berupaya mengetengahkan keterbukaan kepada para stakeholders; (2)Akuntabilitas (accountability) adalah terciptanya sistem pengendalian yang efektif didasarkan atas distribusi dan keseimbangan kekuasaan diantara anggota direksi, pemegang 
saham, komisaris dan pengawas. Para komisaris, direksi dan jajarannya wajib memiliki kemampuan dan integritas untuk menjalankan usaha sesuai dengan aturan dan ketentuan yang berlaku; (3) Tanggung jawab (responsibility) artinya perusahaan sebagai bagian dari masyarakat, bertanggung jawab kepada stakeholders dan lingkungan dimana perusahaan berada. Prinsip ini mengatur pemenuhan tanggung jawab perusahaan dalam masyarakat dan menjalankan aktivitas operasional usaha sesuai dengan peraturan perundang-undangan yang berlaku; (4) Independensi (indepedency) adalah sebagai keadaan dimana perusahaan bebas dari pengaruh atau tekanan pihak lain yang tidak sesuai dengan mekanisme korporasi. Prinsip ini mengharuskan perusahaan menggunakan tenaga ahli dalam setiap divisi atau bagian dalam perusahaannya sehingga pengelolaan perusahaan memiliki kebijakan intern dalam perusahaan yang sesuai dengan peraturan dan hukum yang berlaku, prinsip ini harus dilaksanakan dengan baik agar perushaan tidak mudah di intervensi oleh pihak-pihak dari dalam maupun dari luar yang tidak sesuai dengan peraturan dan hukum yang berlaku; (5) Kewajaran (fairness) adalah kesetaraan perlakuan dari perusahaan terhadap pihakpihak yang berkepentingan sesuai dengan kriteria dan proporsi yang seharusnya. Kesetaraan perlakuan ditekankan agar pihak-pihak yang berkepentingan terhadap perusahaan terlindungi dari kecurangan serta penyalahgunaan wewenang yang dilakukan oleh orang dalam.Good corporate governance juga diharapkan dapat memberi manfaat dan meningkatkan kemampuan kinerja secara finansial maupun nonfinansial. Penerapan prinsip-prinsip tersebut telah dijadikan acuan oleh 
Ni Made Aget Luwih dan Ketut Muliartha RM. Pengaruh...

beberapa negara tak terkecuali di Indonesia. Kelima prinsip tersebut diharapkan dapat menghasilkan keputusan yang lebih optimal. Tata kelola perusahaan yang baik, menunjukan kecenderungan tanggung jawab perusahaan yang lebih besar (Rambo, 2013).

Organisasi bisnis wajib dan harus memastikan bahwa good corporate governance diterapkan disegala aspek bisnis karena diperlukan untuk mendorong terciptanya pasar efisien, transparan, dan konsisten dengan peraturan perundangundangan (KNKG, 2006:3). Bank dunia mendefinisikan good corporate governancesebagai aturan, standar, dan organisasi di bidang ekonomi yang mengatur perilaku pemilik perusahaan, direktur, manajer serta perincian dan penjabaran tugas dan wewenang serta pertanggungjawaban kepada pemegang saham dan kreditur (Siboro, 2007). Kualitas tata kelola perusahaan adalah kondisi yang diperlukan untuk menjamin dan memelihara kepercayaan pemangku kepentingan (Fathi, 2013). Prinsip good corporate governancedibutuhkan agar tercapainya kesinambungan usaha (sustainability) perusahaan dengan memperhatikan stakeholder (KNKG, 2006:5).

Pada organisasi bisnis baik yang bersifat profit oriented maupun organisasi nirlaba selama telah ada penyerahan mandat pengelolaan tugas-tugas organisasi kepada pihak lain maka agency theory akan berlaku dalam organisasi tersebut (Sugiyanto, 2011). Agency theory yang dikembangkan oleh Michael Johnson, memandang manajemen perusahaan sebagai agen bagi shareholder, akan bertindak penuh kesadaran bagi kepentingannya sendiri bukan sebagai pihak yang 
arif dan bijaksana serta adil terhadap pemegang saham (Kaihatu, 2006). Pada organisasi agency theory juga berlaku, karena pengelolaan koperasi diserahkan kepada pengurus sedangkan anggota sebagai pemilik dan pengguna jasa. (Sugiyanto, 2011).

Good corporate governance diimplementasikan untuk membangun budaya dan membangkitkan kesadaran pihak-pihak yang terkait dengan koperasi agar memperhatikan tanggung jawabnya mensejahterkan anggota. Untuk dapat menjalankan fungsi serta perannya yang begitu penting untuk perekonomian maka koperasi harus dikelola secara baik agar dapat meningkatkan kinerjanya secara berkesinambungan. Berdasarkan hal tersebut Kementerian Negara Koperasi dan Usaha Kecil Menengah gencar mensosialisasikan tentang good corporate governance pada koperasi kepada masyarakat agarpengelolaan koperasi dapat dilakukan secara efektif dan efisien dan tidak menyebabkan kerugian pada pihak manapun.

Peningkatan aset yang diikuti peningkatan hasil operasi akan semakin menambah kepercayaan pihak luar terhadap perusahaan. Martono dan Harjito (2003) menyatakan bahwa meningkatnya kepercayaan pihak luar (kreditur) terhadap perusahaan, maka proporsi penggunaan sumber dana hutang semakin lebih besar daripada modal sendiri, hal ini didasarkan pada keyakinan kreditur atas dana yang ditanamkan kedalam perusahaan dijamin oleh besarnya aset yang dimiliki perusahaan. Indiktor yang digunakan untuk mengukur pertumbuhan aset 
Ni Made Aget Luwih dan Ketut Muliartha RM. Pengaruh...

dapat diukur berdasarkan perbandingan antara total aset periode sekarang terhadap total aset periode sebelumnya (Weston J. Fred dan Thomas, 2008).

Laporan keuangan organisasi dapat mencerminkan kinerja keuangan dari suatu organisasi bisnis. Profitabilitas adalah indikator yang tepat digunakan untuk menganalisis kinerja keuangan organisasi bisnis. Nainggolan (2007) menyatakan kinerja keuangan menjadi salah satu aspek penelitian yang fundamental mengenai kondisi yang dimiliki perusahaan. Penelitian ini menggunakan tingkat profitabilitas untuk mengukur kinerja keuangan koperasi. Profitabilitas perusahaan umumnya dianggap sebagai prasyarat penting untuk keberhasilan dan kelangsungan hidup perusahaan dalam jangka panjang (Yazdanfar, 2013). Dalam penelitian ini, profitabilitas koperasi akan diukur menggunakan rasio Return On Asset (ROA). RasioReturn On Asset(ROA) ini dipilih karena Return On Asset(ROA) berfokus terhadap kemampuan perusahaan untuk memperoleh earning dalam operasinya (Sudiyatno dan Suroso, 2010)

Berdasarkan uraian di atas, koperasi memiliki peranan yang penting bagi perekonomian Indonesia selain itu koperasi juga merupakan bagian dari sistem pasar yang akan bersaing dengan unit usaha lainnya dalam pasar yang sama untuk memberikan pelayanan kepada anggota masyarakat sehingga koperasi harus memiliki keunggulan komparatif. Untuk dapat menciptakan sebuah keunggulan yang komparatif maka koperasi selain harus di kelola berdasarkan prinsip-prinsip koperasi tetapi juga penting untuk menerapkan prinsip-prinsip good corporate governanceserta mampu mengelola aset yang dimiliki dengan sebaik-baiknya. 
Berdasarkan hal tersebut peneliti ingin meneliti "Pengaruh Prinsip-Prinsip Good Corporate Governance dan Pertumbuhan Aset Pada Kinerja Keuangan Koperasi Di Kecamatan Denpasar Selatan.

Teori yang digunakan dalam penelitian ini ada dua teori, yaitu teori agensi dan teori stewardship. Teori agensi menjelaskan hubungan keagenan (agency relationship) dimana terdapat suatu kontrak satu orang atau lebih (prinsipal) yang memerintahkan orang lain (agen) untuk melakukan suatu jasa atas nama prinsipal dan memberi wewenang kepada agen untuk membuat keputusan yang terbaik bagi prinsipal. Namun, sebaliknya teori keagenan juga dapat mengimplikasikan adanya asimetri informasi. Konflik keagenan merupakan konflik yang timbul antara pemilik dan manajer dimana ada kecenderungan manajer lebih mementingkan tujuan individu daripada tujuan perusahaan. Konflik keagenan juga dapat terjadi apabila struktur dalam perusahaan tidak jelas dalam pendelegasiannya. Konflik yang dapat terjadi dalam koperasi yaitu dimana anggota sebagai prinsipal dan pengurus sebagai agen. Teori yang kedua adalah teori stewardshipini timbul berdasarkan kepercayaan pada masing-masing pihak. Kepercayaan yang diberikan prinsipal pada steward membuat pihak manajemen sebagai steward termotivasi untuk bertindak sesuai keinginan prinsipal.

Keberadaan good corporate governance dalam perusahaan juga diindikasikan sebagai salah satu faktor yang mempengaruhi kinerja keuangan. Perusahaan yang sudah memiliki nilai tata kelola yang baik akan sangat dipercaya karena telah menerapkan good corporate governance dengan baik, adanya 
Ni Made Aget Luwih dan Ketut Muliartha RM. Pengaruh...

penerapan prinsip-prinsip tata kelola yang baik dalam suatu perusahaan, maka akan memiliki kinerja yang baik karena beberapa kriteria sudah terpenuhi.

Kajian empiris dalam penelitian ini berupa penelitian yang dilakukan Putri (2011) mengambil judul penelitian "Dampak $G C G$ dan Budaya Organisasi Pada Pengaruh Kebijakan Deviden Terhadap Manajemen Laba Serta Konsekuensinya pada Nilai Perusahaan". Hasil penelitian menunjukan GCG berpengaruh negatif terhadap manajemen laba namun budaya organisasi tidak berpengaruh langsung terhadap manajemen laba.

Numaria Rahmatika, Kirmizi dan Restu Agus (2015) melakukan penelitian dengan tujuan untuk menguji pengaruh prinsip-prinsip good corporate governance yang ditujukan oleh transparansi, kemandirian, akuntabilitas, pertanggungjawaban dan kewajaran terhadap kinerja keuangan yang diukur dengan return on asset, penelitian ini mengambil objek pada PT. Angkasa Pura II. Hasil pengujian menunjukan bahwa ukuran transparansi, akuntabilitas, pertanggungjawaban, kemandirian dan kewajaran berpengaruh secara positif signifikan terhadap kinerja keuangan.

Triyana (2012) melakukan penelitian yang bertujuan untuk mengetahui manfaat atau hasil dari penerapan prinsip good corporate governance sehingga akan berpengaaruh pada kinerja keuangan perusahaan.Hasil dari penelitian ini adalah penerapan prinsip good corporate governance pada Perum Pegadaian sangat bermanfaat terhadap kinerja keuangan perusahaan hal ini dapat terlihat dengan diterapkannya prinsip-prinsip good corporate governance sehingga 
membantu dalam setiap proses pengambilan keputusan yang berhubungan dengan keuangan maupun non keuangan yang akan berpengaruh terhadap kinerja keuangan.

Dewi dan Putri (2014) melakukan penelitian yang berjudul "Pengaruh Penerapan Prinsip-Prinsip Good Corporate GovernancePada Kinerja Keuangan Lembaga Perkreditan Desa Kabupaten Gianyar". Hasil penelitian tersebut menyatakan bahwa prinsip-prinsip good corporate governanceberpengaruh positif terhadap kinerja keuangan LPD di Kabupaten Gianyar.

Pradnyaswari (2015) melakukan penelitian yang berjudul "Pengaruh Prinsip-Prinsip Good Corporate Governancepada Kinerja Keuangan Koperasi di Kabupaten Klungkung”. Hasil pengujian hipotesis penelitian tersebut menyatakan bahwa prinsip-prinsip good corporate governance berpengaruh positif terhadap kinerja keuangan koperasi di Kabupaten Klungkung.

Ombayo (2011) melakukan penelitian dengan tujuan untuk menguji pengaruh prkatik tata kelola perusahaan terhadap kinerja keuangan perusahaan yang terdaftar di Bursa Efek Nairobi. Sampel penelitian terdiri dari indeks saham NSE-20. Hasil dari penelitian tersebut adalah perusahaan-perusahaan yang menerapkan good corporate governance di perusahaannya menunjukan kinerja baik dengan probabilitas meningkat $100 \%$ untuk jangka empat tahun, maka dapat disimpulkan praktik-praktik tata kelola perusahaan berpengaruh terhadap kinerja keuangan perusahaan yang terdaftar di Bursa Efek Nairobi periode 2004-2008. 
Ni Made Aget Luwih dan Ketut Muliartha RM. Pengaruh...

Total aset dipilih sebagai ukuran growth dengan mempertimbangkan nilai aset relatif stabil dibandingkan nilai market capitalized dan penjualan (Shudarmadji, 2007). Penelitian yang dilakukan oleh Sriwardany (2006) membuktikan bahwa pertumbuhan aset berpengaruh negatif terhadap kinerja keuangan dan (Kusumasari, Artini dan Nitiyasa2010) membuktikan bahwa pertumbuhan aset berpengaruh tidak signifikan terhadap kinerja keuangan.

Transparancy adalah salah satu prinsip dari GCG yang saat ini menjadi sorotan publik, dimana transparancy merupakan prinsip yang menjamin akses atau kebebasan bagi setiap orang untuk memperoleh informasi tentang pertanggungjawaban organisasi bisnis terhadap pihak yang berkepentingan. Apabila organisasi bisnis menerapkan prinsip transparancy maka akan meningkatkan kepercayaan stakeholder terhadap perusahaan, sehingga kinerja keuangan perusahaan akan menjadi lebih baik. Pentingnya menerapkan prinsip transparancy sebagai pedoman bagi pelaku usaha dalam menjalankan kegiatan usahanya, dibuktikan dengan adanya beberapa penelitian yang berkaitan dengan hal tersebut. Rahmatika (2015), yang menyatakan bahwa penerapan salah satu prinsip GCG yaitu transparancy berpengaruh positif terhadap kinerja keuangan PT. Angkasa Pura II. Hasil penelitian tersebut juga sejalan dengan penelitian yang dilakukan oleh Ombayo (2011), Triyana (2012) dan Pradnyaswari (2015).

$\mathrm{H}_{1}$ : Prinsip transparancy berpengaruh pada kinerja keuangan koperasi di Kecamatan Denpasar Selatan

Martha (2014) menyatakan bahwa accountability merupakan persyaratan mendasar untuk mencegah penyalahgunaan kewenangan yang didelegasikan dan 
menjamin kewenangan diarahkan pada pencapaian-pencapaian tujuan yang diterima secara luas dengan tingkat efisiensi, efektifitas, dan kejujuran. Penelitian Rambo (2013) menyatakan accountability secara parsial berpengaruh secara signifikan terhadap kinerja instansi pemerintah, hal tersebut sejalan dengan penelitian yang dilakukan oleh Rahmatika, dkk., (2015) mendapati hasil bahwa penerapan salah satu prinsip GCG yaitu accountability berpengaruh positif terhadap kinerja keuangan PT. Angkasa Pura II (Persero). Kejelasan wewenang dan fungsi pelaksanaan serta pertanggungjawaban struktur dalam perusahaan akan membuat pengelolaan perusahaan terlaksana secara efektif, dan pada akhirnya akan meningkatkan kinerja keuangan perusahaan.

$\mathrm{H}_{2}$ : Prinsip accountability berpengaruh pada kinerja keuangan koperasi di Kecamatan Denpasar Selatan.

Responsibility yaitu kesesuaian pengelolaan perusahaan terhadap peraturan perundang-undangan yang berlaku dan prinsip-prinsip korporasi sehat, dengan memenuhi tanggungjawab kepada masyarakat dan lingkungan serta mengacu pada peraturan perundang-undangan dan prinsip-prinsip korporasi sehat sebagai pedoman pengelolaan perusahaan, diharapkan dapat meningkatkan citra dan kinerja perusahaan yang akan berdampak pada keberlangsungan perusahaan dalam jangka panjang. Hasil penelitian Suci (2013) responsibility secara parsial berpengaruh terhadap kinerja perusahaan. Hal tersebut sejalan dengan penelitian Rahmatika, dkk., (2015) menunjukan hasil bahawa prinsip responsibility berpengaruh pada kinerja keuangan PT. Angkasa Pura II (Persero) karena untuk dapat meningkatkan kinerjanya, perusahaan harus mampu memahami dan 
Ni Made Aget Luwih dan Ketut Muliartha RM. Pengaruh...

mematuhi peraturan serta melaksanakan tanggung jawab terhadap stakeholders sehingga perusahaan dapat tumbuh secara berkeseimbangan. Mematuhi peraturan dan melaksanakan tanggung jawabnya dengan efektif, maka kinerja keuangan perusahaan akan meningkat.

$\mathrm{H}_{3}$ : Prinsip responsibility berpengaruh pada kinerja keuangan Koperasi di Kecamatan Denpasar Selatan.

Indepedency adalah suatu keadaan dimana perusahaan dikelola secara profesional tanpa benturan kepentingan dan pengaruh tekanan dari pihak manapun yang tidak sesuai dengan peraturan perundang-undangan yang berlaku dan prinsip-prinsip korporasi yang sehat Suci (2013). Kebebasan mengelola perusahaan tanpa benturan kepentingan dari pihak lain penting untuk diperhatikan dalam usaha unuk meningkatkan kinerja dan memastikan bahwa perusahaan telah bersikap secara objekif. Rahmatika (2015) dalam penelitiannya menunjukan bahwa terdapat pengaruh positif dari penerapan kemandirian (indepedency) terhadap kinerja.

$\mathrm{H}_{4}$ : Prinsip indepedency berpengaruh pada kinerja koperasi di Kecamatan Denpasar Selatan

Fairness merupakan keadilan dan kesejahteraan dalam memenuhi hak-hak stakeholders yang timbul berdasarkan perjanjian dan perundang-undangan yang berlaku. Kewajaran merujuk pada keadilan dan kesetaraan dalam memenuhi hakhak pemangku kepentingan yang timbul sebagai akibat dari perjanjian dan peraturan perundang-undangan yang berlaku. Proses pengambilan keputusan berdasarkan asas kewajaran ini akan menghasilkan keputusan yang adil bagi 
semua pihak yang berkepentingan terhadap perusahaan, sehingga tercipta iklim yang kondusif dalam perusahaan yang berujung pada peningkatan kinerja perusahaan kearah yang lebih baik. Rahmatika dkk, (2015) menyatakan pengaruh antara kewajaran terhadap kinerja keuangan menunjukan hasil positif, hal ini menunjukan bahwa kewajaran berpengaruh terhadap kinerja keuangan. Hasil penelitian ini menunjukan bahwa kewajaran berpengaruh terhadap kinerja keuangan. Organisasi bisnis seyogyanya dapat memperhatikan hak dari pemangku kepentingan berdasarkan atas kewajaran dan kesetaraan dalam rangka meningkatkan kinerja keuangan perusahaan.

$\mathrm{H}_{5}$ : Prinsip fairnessberpengaruh pada kinerja keuangan koperasi di Kecamatan Denpasar Selatan.

Pengukuran kinerja perusahaan dapat dilihat dari tingkat profitabilitas. Profitabilitas adalah kemampuan memperoleh laba dalam hubungannya dengan penjualan, total aktiva, maupun modal sendiri. Growth mempengaruhi profitabilitas, melalui aset yang dimiliki sehingga berpengaruh terhadap produktivitas dan efesiensi perusahaan yang pada akhirnya berpengaruh pada profitabilitas. Total aset dipilih sebagi ukuran growth dengan mempertimbangkan nilai aset relatif stabil dibandingkan nilai market capitalized dan penjualan (Shudarmadji, 2007). Penelitian yang dilakukan oleh (Sriwardany, 2006) yang berjudul "Pengaruh Pertumbuhan Aset Dan Struktur Modal Pada Kinerja Keuangan Perusahan" membuktikan bahwa pertumbuhan aset berpengaruh negatif terhadap kinerja keuangan dan (Kusumasari,2009) membuktikan bahwa pertumbuhan aset berpengaruh tidak signifikan terhadap kinerja keuangan. 
Ni Made Aget Luwih dan Ketut Muliartha RM. Pengaruh...

$\mathrm{H}_{6}$ : Pertumbuhan aset berpengaruh pada kinerja keuangan koperasi di Kecamatan Denpasar Selatan.

\section{METODE PENELITIAN}

Lokasi atau ruang lingkup wilayah penelitian ini dilakukan pada koperasi yang berada di kecamatan Denpasar Selatan, dengan memberikan kuesioner dan mencari laporan keuangan hasil RAT tahun 2014 - 2016 pada koperasi yang dijadikan sampel penelitian.

Variabel bebas dalam penelitian ini adalah prinsip-prinsip good corporate governance yang terdiri dari transparancy $\left(\mathrm{X}_{1}\right)$ accountabillity $\left(\mathrm{X}_{2}\right)$, responsibillity $\left(\mathrm{X}_{3}\right)$, independency $\left(\mathrm{X}_{4}\right)$, dan fairness $\left(\mathrm{X}_{5}\right)$, pertumbuhan aset $\left(\mathrm{X}_{6}\right)$. Variabel terikat (Y) dalam penelitian ini adalah kinerja keuangan yang di ukur menggunakan return on asset (ROA).

Populasi dalam penelitian ini adalah seluruh koperasi di Kecamatan Denpasar Selatan yang tergolong aktif. Berdasarkan data yang diperoleh dari Dinas Koperasi, UKM, Perindustrian dan Perdagangan Kota Denpasar.Metode pengambilan sampel dalam penelitian ini menggunakan metode purposive sampling.

Rincian perhitungan untuk jumlah sampel akan dijelaskan pada tabel 1.sebagai berikut:

Tabel 1.

Rincian Perhitungan Penentuan Jumlah Sampel Penelitian

\begin{tabular}{clc}
\hline No & \multicolumn{1}{c}{ Kriteria } & Jumlah Koperasi \\
\hline 1 & Koperasi Simpan Pinjam di Kecamatan Denpasar Selatan & 65 \\
2 & Koperasi Simpan Pinjam yang tidakaktif & $(3)$
\end{tabular}


2016.

4 Koperasi yang tidak mempunyai data aset dan SHU tahun 2014-2016

Jumlah koperasi amatan

Responden terpilih

Jumlah sampel

60

Sumber: Data diolah, 2018

Statistik deskriptif digunakan untuk memberikan gambaran atau deskripsi variabel dalam penelitian ini yang dilihat dari nilai rata-rata, standar deviasi, varian, nilai maksimun dan nilai minimun (Ghozali, 2012:19). Data yang dianalisis adalah prinsip-prinsip good corporate governance yang terdiri dari transparancy, accountability, responsibility, indepedency, fairness dan pertumbuhan aset serta kinerja keuangan.

Teknik analisis data yang digunakan dalam penelitian ini adalah teknik analisis regresi linier berganda melalui program komputer SPSS. Analisis regresi linier berganda digunakan karena penelitian ini menggunakan lebih dari satu variabel independen. Adapun rumus regresinya sebagai berikut.

$$
Y=\alpha+\beta_{1} X_{1}+\beta_{2} X_{2}+\beta_{3} X_{3}+\beta_{4} X_{4}+\beta_{5} X_{5}+\beta_{6} X_{6}+e
$$

Keterangan:

$\begin{array}{ll}\mathrm{Y} & =\text { Variabel terikat (kinerja keuangan) } \\ \alpha & =\text { Konstanta } \\ \beta_{1}, \beta_{2}, \beta_{3}, \beta_{4}, \beta_{5}, \beta_{6} & =\text { Koefisien regresi untuk } \mathrm{X}_{1, \mathrm{X}_{2}, \mathrm{X}_{3}, \mathrm{X}_{4}, \mathrm{X}_{5}, \mathrm{X}_{6}} \\ \mathrm{X}_{1} & =\text { Variabel bebas(transparancy) } \\ \mathrm{X}_{2} & =\text { Variabel bebas(accountability) } \\ \mathrm{X}_{3} & =\text { Variabel bebas(responsibility) } \\ \mathrm{X}_{4} & =\text { Variabel bebas(indepedency) }\end{array}$




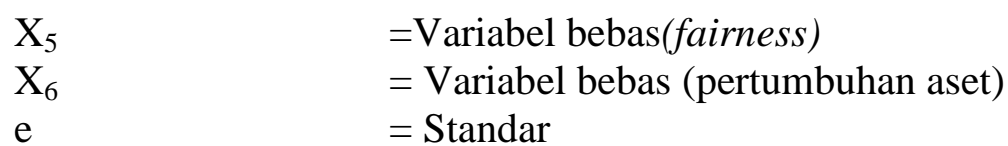

\section{HASIL PENELITIAN DAN PEMBAHASAN}

Hasil statistik deskriptif dalam penelitian ini ditunjukkan dalam Tabel 2. berikut:

Tabel 2.

Hasil Uji Statistik Deskriptif Variabel Independen dan Dependen

\begin{tabular}{cccccc}
\hline & N & Minimum & Maximum & Mean & Std. Deviation \\
\hline Kinerja Keuangan (Y) & 60 &, 000 &, 108 & 0,03635 &, 027542 \\
Transparancy (X1) & 60 & 12,000 & 24,000 & 18,0666 & 3,918088 \\
Accountability (X2) & 60 & 12,000 & 24,000 & 18,0833 & 3,906933 \\
Responsibility (X3) & 60 & 12,000 & 24,000 & 18,2500 & 4,019550 \\
Indepedency (X4) & 60 & 12,000 & 24,000 & 18,0833 & 3,915600 \\
Fairness (X5) & 60 & 12,000 & 24,000 & 17,9666 & 3,817740 \\
Pertumbuhan aset (X6) & 60 &, 030 &, 597 &, 29660 &, 181115 \\
Valid N (listwise) & 60 & & & & \\
\hline Sumber: Data diolah, 2018 & & & &
\end{tabular}

Sumber: Data diolah, 2018

Berdasarkan hasil olahan SPSS dalam Tabel 2. statistik deskriptif untuk variabel independen yaitu prinsip-prinsip good corporate governance yang diukur melalui kuesioner dan pertumbuhan aset diukur dengan rumus total aset tahun ini dikurangkan total aset tahun sebelumnya dibagi total aset tahun sebelumnyamemaparkan nilai minimum, nilai maksimum, rata-rata dan standar deviasi dengan jumlah 60 kasus.

Nilai minimum untuk variabel transparancy yaitu X1 adalah 12,000, nilai maksimum sebesar 24,000, rata-rata penerapan variabel 18,0666dengan penyimpangan nilai variabel terhadap nilai rata-ratanya yang ditunjukkan melalui standar deviasi yaitu sebesar 3,918088. 
Nilai minimum untuk variabel accountability yaitu X2 adalah 12,000, nilai maksimum sebesar24,000, rata-rata penerapan variabel 18,0833dengan penyimpangan nilai variabel terhadap nilai rata-ratanya yang ditunjukkan melalui standar deviasi yaitu sebesar 3,906933.

Nilai minimum untuk variabel responsibility yaitu X3 adalah 12,000, nilai maksimum sebesar 24,000, rata-rata penerapan variabel 18,2500dengan penyimpangan nilai variabel terhadap nilai rata-ratanya yang ditunjukkan melalui standar deviasi yaitu sebesar 4,019550.

Nilai minimum untuk variabel indeppedency yaitu X4 adalah 12,000, nilai maksimum sebesar 24,000 rata-rata penerapan variabel 18,0833dengan penyimpangan nilai variabel terhadap nilai rata-ratanya yang ditunjukkan melalui standar deviasi yaitu sebesar 3,915600.

Nilai minimum untuk variabel fairness yaitu X5 adalah 12,000, nilai maksimum sebesar 24,000 rata-rata penerapan variabel 17,9666dengan penyimpangan nilai variabel terhadap nilai rata-ratanya yang ditunjukkan melalui standar deviasi yaitu sebesar 3,817740.

Variabel pertumbuhan aset memiliki nilai minimum sebesar 0,30 nilai maksimum 0,597 rata-rata penerapan variabel 0,29660 dengan penyimpangan nilai variabel terhadap nilai rata-ratanya yang ditunjukan melalui standar deviasi yaitu sebesar 0,181115. Hal ini menunjukan bahwa nilai standar deviasi lebih kecil dibandingkan dengan nila rata-rata, yang berarti bahwa pertumbuhan aset memiliki fluktuasi yang kecil. 
Ni Made Aget Luwih dan Ketut Muliartha RM. Pengaruh...

Kinerja keuangan memiliki nilai minimum sebesar 0,000 nilai maksimum 0,108 rata-rata penerapan variabel 0,3635 dengan penyimpangan nilai variabel terhadap nilai rata-ratanya yang ditunjukkan melalui standar deviasi yaitu sebesar0,027542.

Penelitian menggunakan koefisien determinasi untuk mengukur seberapa jauh kemampuan model dalam menerangkan variasi variabel dependen (Ghozali, 2012:97). Untuk dapat melihat seberapa besar kontribusi prinsip good corporate governance memengaruhi kinerja keuangan, dapat dilihat pada nilai koefisien adjusted $\mathrm{R}^{2}$ yang tertera pada Tabel 3 .

Tabel 3.

Hasil Uji Koefisien Determinasi

\begin{tabular}{crrrr}
\hline Model & R & R Square & Adjusted R Square & $\begin{array}{c}\text { Std. Error of the } \\
\text { Estimate }\end{array}$ \\
\hline 1 &, $623^{\text {a }}$ &, 388 &, 318 &, 022741 \\
\hline Sumber: Data diolah, 2018 & & &
\end{tabular}

Dari hasil output SPSS model summary yang dinyatakan dalam Tabel 3 untuk dapat mengetahui seberapa besar penerapan prinsip-prinsip good corporate governance dan pertumbuhan aset memengaruhi kinerja keuangan, dapat dilihat dari nilai koefisien adjusted $\mathrm{R}^{2}$ adalah 0,318 hal ini berarti $31,8 \%$ variasi kinerja keuangan dapat dijelaskan oleh variasi dari kedua variabel independen yaitu prinsip-prinsip good corporate governance. Sedangkan sisanya 68,2\% (100\%$31,8 \%$ ) dijelaskan oleh faktor lain diluar model.

Uji F dilakukan dengan melihat nilai signifikasi pada tabel Annova dengan bantuan program SPSS yaitu dengan membandingkan tingkat signifikasi variabel bebas dengan $\alpha=0,05$. Apabila tingkat signifikansi $\mathrm{F}<\alpha=0,05$ maka $\mathrm{H}_{0}$ ditolak, 
dan sebaliknya jika tingkat signifikansi $\mathrm{F} \geq \alpha=0,05$ maka $\mathrm{H}_{0}$ diterima (Ghozali, 2012:98). Hasil uji kelayakan model (uji F) akan disajikan dalam tabel 4.10 sebagai berikut.

Tabel 4.

Hasil Kelayakan Model (Uji F)

\begin{tabular}{ccccccc}
\hline & & Sum of & & & & \\
& Model & Squares & Df & Mean Square & F & Sig. \\
\hline \multirow{3}{*}{1} & Regression & 0,17 & 6 &, 003 & 5,591 &, $000^{\text {b }}$ \\
& Residual & 0,27 & 53 &, 001 & & \\
& Total &, 045 & 59 & & & \\
\hline
\end{tabular}

Sumber: Data diolah, 2018

Dari hasil uji Anova atau F test didapatkan hasil bahwa nilai F sebesar 5,591 dengan probabilitas 0,000 . Karena probabilitas $<0,05$ maka model regresi dapat digunakan untuk memprediksi prinsip-prinsip good corporate governance dan pertumbuhan aset. Hal ini menunjukan bahwa model ini layak digunakan untuk dianalisis.

Interpretasi dari persamaan regresi linier berganda digunakan untuk menemukan persamaan dalam penelitian yang dilakukan, hal tersebut dapat digunakan untuk menentukan model penelitian dan untuk menjelaskan pengaruh masing-masing variabel independen terhadap variabel dependen.

Tabel 5.

Hasil Uji Statistik t (Uji Signifikansi Parameter Individual)

\begin{tabular}{|c|c|c|c|c|c|c|}
\hline & \multirow[t]{2}{*}{ Model } & \multicolumn{2}{|c|}{ Unstandardized Coefficients } & \multirow{2}{*}{$\begin{array}{c}\text { Standardized } \\
\text { Coefficients } \\
\text { Beta } \\
\end{array}$} & \multirow[t]{2}{*}{$\mathbf{t}$} & \multirow[t]{2}{*}{ Sig. } \\
\hline & & B & Std. Error & & & \\
\hline \multirow{7}{*}{1} & (Constant) &, 12363 & ,01704 & & 7,257 & ,000 \\
\hline & $\mathrm{X} 1$ &,- 0017 & 00109, &,- 241 & $-1,561$ & , 125 \\
\hline & $\mathrm{X} 2$ & ,00033 & ,00107 & ,047 & ,309 & ,759 \\
\hline & $\mathrm{X} 3$ &,- 00259 & ,00125 &,- 377 & $-2,064$ & ,044 \\
\hline & $\mathrm{X} 4$ &,- 00075 & ,00126 &,- 107 &,- 598 &, 552 \\
\hline & $\mathrm{X} 5$ & ,00011 & ,00115 & ,016 & ,098 & ,922 \\
\hline & X6 &,- 01306 & ,01669 &,- 086 &,- 782 & , 437 \\
\hline
\end{tabular}


Ni Made Aget Luwih dan Ketut Muliartha RM. Pengaruh...

Sumber: Data diolah, 2018

Berdasarkan hasil olahan SPSS yang tertera pada Tabel 4.11 maka persamaan regresi linier berganda dapat dirumuskan sebagai berikut.

$\mathrm{Y}=0,12363-0,0017 \mathrm{X}_{1}+0,00033 \mathrm{X}_{2^{-}} 0,0259 \mathrm{X}_{3}-0,00075 \mathrm{X}_{4}+0,00011 \mathrm{X}_{5}-$ $0,1306 X_{6}$

Adapun arti dari koefisien tersebut akan dijelaskan bahwa nilai konstanta 0,12363 memiliki arti bahwa apabila penerapan prinsip-prinsip good corporate governance konstan pada angka tersebut, maka kinerja keuangan akan meningkat.

Nilai koefisien regresi transparancy $\left(\mathrm{X}_{1}\right)$ sebesar -0,0017 memiliki arti bahwa apabila variabel transparancy meningkat sebesar satu - satuan dalam penerapannya, maka akan diikuti dengan penurunan kinerja keuangan sebesar 0,0017 .

Nilai koefisien accountability $\left(\mathrm{X}_{2}\right)$ sebesar 0,00033 berarti apabila variabel accountability mengalami peningkatan ketika penerapannya, maka kinerja keuangan akan meningkat.

Nilai koefisien responsibility $\left(\mathrm{X}_{3}\right)$ sebesar -0,0259 memiliki arti bahwa apabila variabel responsibility meningkat sebesar satu - satuan dalam penerapannya, maka akan diikuti dengan penurunan kinerja keuangan sebesar 0,0259.

Nilai koefisien indepedency $\left(\mathrm{X}_{4}\right)$ sebesar $-0,00075$ dapat diartikan apabila variabel kewajaran meningkat sebesar satu-satuan, maka akan diikuti dengan penurunan kinerja keuangan (Y) sebesar 0,00075. 
Nilai koefisien fairness $\left(\mathrm{X}_{5}\right)$ sebesar 0,00011 dapat diartikan apabila variabel kewajaran meningkat sebesar satu-satuan, maka akan diikuti dengan peningkatan kinerja keuangan (Y) sebesar 0,00011.

Nilai koefisien pertumbuhan aset $\left(\mathrm{X}_{6}\right)$ sebesar -0,1306 dapat diartikan apabila variabel pertumbuhan aset meningkat sebesar satu-satuan, maka akan diikuti dengan penurunan kinerja keuangan (Y) sebesar 0,1306.

Berdasarkan hasil olahan SPSS yang termuat dalam Tabel 5 dinyatakan nilai p-value untuk variabel transparancy sebesar $0,125>\alpha=0,050$ maka $\mathrm{H}_{1}$ diterima. Hal ini menunjukkan bahwa semakin kurang transparan koperasi dalam mengungkapkan informasi mengenai keadaan koperasi menyebabkan penurunan kepercayaan stakeholder dalam hal ini anggota, maka kinerja keuangan koperasi tersebut akan menurun pula. Hasil tersebut juga mendukung penelitian terdahulu yang dilakukan oleh Irwondy (2014) Gelaura (2009) yang menyatakan bahwa tidak terdapat pengaruh yang signifikan secara parsial penerapan prinsip transparancy terhadap kinerja perusahaan. Bertentangan dengan penelitian Numaria Rahmatika, Kirmizi dan Restu Agus (2015), Triyana (2012), Dewi dan Putri (2014), Pradnyaswari (2015), dan Ombayo (2011), yang menyatakan bahwa penerapan prinsip transparancy berpengaruh positif terhadap kinerja keuangan.

Berdasarkan hasil olahan SPSS yang termuat dalam Tabel 5 dinyatakan nilai p-value untuk variabel accountability sebesar 0,759 $>\alpha=0,050$ maka $\mathrm{H}_{2}$ ditolak. Hasil tersebut tidak mendukung $\mathrm{H}_{2}$ yang menyatakan bahwa accountability berpengaruh positif pada kinerja keuangan koperasi di Kecamatan Denpasar 
Ni Made Aget Luwih dan Ketut Muliartha RM. Pengaruh...

Selatan. Hal ini menunjukkan bahwa masih kurang jelasnya wewenang dan fungsi pelaksanaan serta pertanggungjawaban struktur organisasi dalam perusahaan sehingga pengelolaan perusahaan terlaksana kurang efektif. Hasil tersebut juga mendukung penelitian terdahulu yang dilakukan oleh Hasil tersebut mendukung hasil penelitian terdahulu oleh Irwondy (2014), Gelaura (2009) yang menyatakan bahwa tidak terdapat pengaruh yang signifikan secara parsial penerapan prinsip accountability terhadap kinerja perusahaan.

Berdasarkan hasil olahan SPSS yang termuat dalam Tabel 5 dinyatakan nilai p-value untuk variabel responsibility sebesar $0,044<\alpha=0,050$ maka $\mathrm{H}_{3}$ diterima. Semakin kuat peraturan yang ada maka meningkatkan tanggung jawab terhadap stakeholder namun hal itu juga dapat membuat kejenuhan karyawan sehingga akan dapat menurunkan kinerja keuangan koperasi.Hasil tersebut juga mendukung penelitian terdahulu yang dilakukan Eveline (2017), yang menyatakan bahwa penerapan prinsip responsibility berpengaruh negatif terhadap kinerja keuangan.

Berdasarkan pengujian hipotesis pada Tabel 5 variabel independency memiliki nilai signifikansi sebesar $0,552>\alpha=0,050$. Pengujian ini menunjukan bahwa variabel independency tidak berpengaruh signifikan pada kinerja keuangan koperasi di Kecamatan Denpasar Selatan sehingga rumusan hipotesis $\mathrm{H}_{4}$ ditolak. Hal ini mengindikasikan bahwa penerapan prinsip indepedency pada koperasi di Kecamatan Denpasar Selatan dapat dikatakan cukup baik. Indepedency yang dimaksud dalam proses pengambilan keputusan, pengurus sudah dapat mengambil keputusan secara objektif atau bebas dari kepentingan berbagai pihak yang dapat 
merugikan koperasi, selain itu ketua koperasi juga sudah mampu menghindari adanya dominasi oleh pihak lain, sehingga dapat dikatakan bahwa penerapan prinsip independensi dalam pengelolaan koperasi dapat dikatakan cukup baik. Tetapi walaupun penerapan prinsip ini dapat dikatakan cukup baik, nyatanya masih belum dapat mendorong peningkatan kinerja keuangan koperasi, sehingga perlu dilakukan peningkatan dalam proses penerapan prinsip ini secara berkelanjutan, sehingga diharapkan akan berdampak pada peningkatan kinerja keuangan koperasi.

Hasil tersebut mendukung hasil penelitian terdahulu oleh Irwondy (2014). yang menyatakan bahwa tidak terdapat pengaruh yang signifikan secara parsial penerapan prinsip indepedency terhadap kinerja perusahaan. Bertentangan dengan penelitian yang dilakukan oleh Numaria Rahmatika, Kirmizi dan Restu Agus (2015), Triyana (2012), Dewi dan Putri (2014), Pradnyaswari (2015), dan Ombayo (2011), yang menyatakan bahwa penerapan prinsip indepedency berpengaruh positif terhadap kinerja keuangan.

Berdasarkan pengujian hipotesis pada Tabel 5dinyatakan nilai p-value untuk variabel pertumbuhan aset sebesar $0,922>\alpha=0,050$ maka $\mathrm{H}_{5}$ ditolak. Pengujian ini menunjukan bahwa variabel fairness tidak berpengaruh signifikan pada kinerja keuangan koperasi sehingga rumusan hipotesis $\mathrm{H}_{5}$ ditolak. Hal ini mengindikasikan bahwa penerapan prinsip fairness (kewajaran) pada koperasi di Kecamatan Denpasar Selatan dapat dikatakan cukup. Kewajaran yang dimaksud yaitu memberikan kesempatan yang sama pada anggota koperasi untuk 
Ni Made Aget Luwih dan Ketut Muliartha RM. Pengaruh...

memberikan masukan dan pendapat pada koperasi, memberikan perlakuan adil kepada semua anggota. Tetapi walaupun penerapan prinsip ini dapat dikatakan cukup baik, nyatanya masih belum dapat mendorong peningkatan kinerja keuangan koperasi, sehingga perlu dilakukan peningkatan dalam proses penerapan prinsip ini secara berkelanjutan, sehingga diharapkan akan berdampak pada peningkatan kinerja keuangan koperasi.

Hasil tersebut mendukung hasil penelitian terdahulu oleh Irwondy (2014) yang menyatakan bahwa tidak terdapat pengaruh yang signifikan secara parsial penerapan prinsip kewajaran terhadap kinerja perusahaan. Bertentangan dengan penelitian yang dilakukan oleh Numaria Rahmatika, Kirmizi dan Restu Agus (2015), Triyana (2012), Dewi dan Putri (2014), Pradnyaswari (2015), dan Ombayo (2011), yang menyatakan bahwa penerapan prinsip kewajaran berpengaruh positif terhadap kinerja keuangan.

Berdasarkan pengujian hipotesis pada Tabel 5 variabel pertumbuhan aset dinyatakan nilai $\mathrm{p}$-value untuk variabel pertumbuhan aset sebesar $0,437>\alpha=$ 0,050 maka $\mathrm{H}_{5}$ ditolak. Pengujian ini menunjukan bahwa variabel pertumbuhan aset tidak berpengaruh pada kinerja keuangan koperasi sehingga rumusan hipotesis $\mathrm{H}_{6}$ ditolak yang artinya peningkatan aset akan semakin menambah kepercayaan pihak luar terhadap perusahaan. Meningkatnya kepercayaan pihak luar (kreditur) terhadap perusahaan, maka proporsi penggunaan sumber dana hutang semakin lebih besar daripada modal sendiri, namun dengan meningkatnya hutang daripada modal sendiri akan dapat memicu penurunan didalam mencapai 
kinerja keuangan yang baik.Hasil tersebut mendukung hasil penelitian terdahulu oleh Gelaura (2009), menunjukan bahwa pertumbuhan aset tidak berpengaruh terhadap kinerja keuangan perusahaan. Bertentangan dengan penelitian yang dilakukan oleh (Sriwardany, 2006) yang menyatakan bahwa pertumbuhan aset berpengaruh negatif terhadap kinerja keuangan.

Dampak yang sangat penting dari adanya penelitian ini adalah bisa memberikan implikasi kepada pelaku ekonomi dalam penelitian ini adalah koperasi yang ada di Kecamatan Denpasar Selatan.Prinsip-prinsip good corporate governance merupakan konsep yang sangat penting untuk diterapkan oleh koperasi pada jaman ini. Untuk meningkatkan kinerja keuangan dari koperasi, perlu pemahaman dari konsep good corporate governance untuk meningkatkan nilai dari koperasi itu sendiri. Hanya prinsip responsibility yang berpengaruh sehingga prinsip ini lebih dominan diperhatikan oleh koperasi di Kecamatan Denpasar Selatan. Hal ini mengandung implikasi supaya kedepannya koperasi tidak hanya memperhatikan sebagaian aspek dari prinsip-prinsip good corporate governance namun selalu menerapkan kelima aspek prinsip-prinsip good corporate governance antara lain transparancy, accountability, responsibility, indepedency, dan fairness guna meningkatkan kinerja keuangan koperasi itu sendiri agar tetap sehat.

Variabel pertumbuhan aset dalam penelitian ini diukur dengan menggunakan persentase kenaikan atau penurunan aset dari suatu periode ke periode berikutnya. Pertumbuhan aset mencerminkan seberapa besar aktiva yang 
Ni Made Aget Luwih dan Ketut Muliartha RM. Pengaruh...

dimiliki oleh suatu perusahaan serta mencerminkan ukuran dari perusahaan. Hasil penelitian ini menunjukan bahwa pertumbuhan aset tidak berpengaruh pada kinerja keuangan koperasi di Kecamatan Denpasar Selatan. Hal ini menunjukkan bahwa koperasi yang ada di Kecamatan Denpasar Selatan dalam mengelola total asetnya belum mampu memaksimalkan dalam pengelolaannya. Hal ini mengandung implikasi supaya seluruh koperasi mampu mengelola dan meningkatkan total asetnya agar selalu mampu meningkatkan kinerja keuangan koperasi di Kecamatan Denpasar Selatan.

\section{SIMPULAN DAN SARAN}

Berdasarkan pada hasil analisis dan data serta pembahasan pada bab sebelumnya mengenai pengaruh prinsip-prinsip good corporate governance dan pertumbuhan aset pada kinerja keuangan koperasi di Kecamatan Denpasar Selatan, maka dapat disimpulkan bahwa prinsip transparancy tidak berpengaruh signifikan pada kinerja keuangan di Kecamatan Denpasar Selatan.Prinsip accountability tidak berpengaruh signifikan pada kinerja keuangan di Kecamatan Denpasar Selatan.Prinsip responsibility berpengaruh negatif pada kinerja keuangan di Kecamatan Denpasar Selatan. Prinsip indepedency tidak berpengaruh signifikan pada kinerja keuangan di Kecamatan Denpasar Selatan.Prinsip fairness tidak berpengaruh signifikan pada kinerja keuangan di Kecamatan Denpasar Selatan.Pertumbuhan aset tidak berpengaruh signifikan kinerja keuangan di Kecamatan Denpasar Selatan. 
Berdasarkan simpulan diatas, maka dapat dinyatakan beberapa saran bahwa koperasi sebagai organisasi yang memiliki peranan penting dalam perekonomian selain mempertimbangkan prinsip koperasi dalam kegiatan operasionalnya tetapi mempertimbangkan pula pengaruh prinsip-prinsip good corporate governance yang dapat meningkatkan kinerja keuangannya. Maka disarankan kepada seluruh koperasi diseluruh Bali juga menerapkan prinsip-prinsip good corporate governance dengan baik. Melakukan evaluasi kinerja harus selalu dilakukan agar kinerja koperasi dapat selalu diawasi agar tetap berjalan secara efektif. Dengan menghasilkan kinerja yang baik maka koperasi akan bisa mewujudkan tujuannya dalam membantu perekonomian masyarakat.

Pada penelitian selanjutnya, diharapkan dapat memilih koperasi di wilayah yang berbeda untuk menyempurnakan penelitian agar dapat mencakup wilayah seluruh Bali. Begitu pula diharapkan untuk memperluas objek dan menambah variabel penelitian sebagai komitmen organisasi, struktur modal dan untuk mengukur kinerja tidak hanya pada aspek keuangan saja tetapi juga mengukur pada aspek non keuangan.

\section{REFERENSI}

Dewi, Krismaya Kadek \& Dwija Putri, I GAM Asri, 2014. Pengaruh Penerapan Prinsip-prinsip Good Corporate Governance pada Kinerja Keuangan Lembaga Perkreditan Desa Kabupaten Gianyar Bali. E-Jurnal Akuntansi Universitas Udayana, 7(3):h:559-573.

Fathi, J. 2013. Corporate Governance System and Quality of Financial Information. Mediterranien Journal of Social Sciences, 4(2):pp 129.

Fathi, J. 2013. Corporate Governance and The Level of Financial Disclosure by Tunisian Firm. Journal of Business Studies Quarterly, 4(3). 
Ni Made Aget Luwih dan Ketut Muliartha RM. Pengaruh...

Eveline, W. 2017. Pengaruh Corporate Responsibility Terhadap Kinerja Keuangan Perusahaan Manufaktur Yang Terdaftar di Bursa Efek Indonesia. Jurnal Ekonomi Unsrat Vol 5 No. 2.

Gelaura, Iashika. 2009. Pengaruh Ukuran Perusahaan, Pertumbuhan Aset, Leverage Keuangan Dan Mekanisme Internal Corporate Governance Terhadap Kinerja Keuangan Perusahaan. Skripsi. Fakultas Ekonomi Universitas Andalas.

Ghozali, Imam dan A. Chariri. 2007. Teori Akuntansi, Badan penerbit Universitas Diponogoro : Semarang

Ghozali, H. Imam, 2012. Aplikasi Analisis Multivariate dengan Program IBM SPSS. Edisi Enam. Semarang: Universitas Diponogoro.

Irwondy, Irvian Syahbani. 2014. Pengaruh Penerapan Konsep Good Corporate GovernanceTerhadap Kinerja Keuangan Di Kantor Pusat PT Asuransi Jasa Indonesia. Skripsi. Program Sarjana Alih Jenis Manajemen Departemen Manajemen Fakultas Ekonomi dan Manajemen Institut Pertanian Bogor.

Kaihatu, T. S, 2006. Good Corporate Governance dan Penerapannya di Indonesia. JournalManajemen dan Kewirausahaan, 8(1),pp:11.

Keputusan Menteri Koperasi dan UKM, Kep.Men.No.06/Per/M.KUKM/V/2006.

Komite Nasional Kebijakan Governance (KNKG). 2006. Pedoman Umum Good Corporate Governance Indonesia, Jakarta.

Kusumasari , Artini, dan Nitiyasa. (2010). Pengaruh Risiko Bisnis, Pertumbuhan Aset, dan Struktur Modal Terhadap Kinerja Keuangan di PT Telekomunikasi Selular. Jurnal Ekonomi, 5(3).

Martha, W. 2014. Pengaruh Transparansi dan Akuntabilitas Terhadap Kinerja Instansi Pemeritah pada Dinas di Kota Bandung (Survey di Instansi Pemeritah Kota Bandung). Doctoral dissertation, Universitas Widyatama.

Martono dan Harjito. 2003. ManajemenKeuangan. Edisi Pertama. Yogyakarta: Penerbit Ekomisia.

Nainggolan, Hiras M. 2007. Pengaruh Rasio Aktivitas terhadap Return on Investment (ROI) pada PT. Hutan BarumunPerkasa Medan. Skripsi Sarjana Fakultas Ekonomi Universitas Sumatra Utara, Medan.

Ombayo, J. O. 2011. The Effect of Corporate Governance on A Firm's Financial Performance: A Case Study Of Companies Listed on The Nairobi Stock Exchange. Doctoral Dissertation, University of Nairobi, Kenya.

Pradnyaswari, A. dan Putri Asri Dwija, I GAM. 2015. Pengaruh Prinsip-Prinsip Good Corporate Governance Pada Kinerja Keuangan Koperasi di 
Kabupaten Klungkung. Jurnal Fakultas Ekonomi dan Bisnis Universitas Udayana.

Putri, IGAM Asri Dwija, 2011. Dampak Good Corporate Governance dan budaya Organisasi pada Pengaruh Kebijakan Deviden Terhadap Manajemen Laba Serta Konsekuensinya pada nilai perusahaan. Doctoral Dissertation, Fakultas Ekonomi dan Bisnis Universitas Brawijaya.

Rahmatika, N., Kirmizi dan Agus, R. 2015. Pengaruh Penerapan Prinsip-prinsip Good Corporate Governance Terhadap Kinerja Keuangan Perusahaan (Studi pada PT Angkasa Pura II). Journal Akuntansi (Media Riset Akuntansi \& Keuangan), 3(2), h:148-156.

Rambo, Charles M. 2013. Influence Of The Capital Markets Authority's Corporate Governance Guidelines On Financial Performance Of Commercial Banks In Kenya. The International Journal of Business and Finance Research, 7 (3).

Siboro, D. T. 2007. Hubungan Good Corporate Governance (GGG) dengan Pengungkapan Laporan Keuangan. Journal Fokus Ekonomi, 2(2):h:17, 29.

Sriwardany. 2006. Pengaruh Pertumbuhan Perusahaan dan Struktur Modal Terhadap Kinerja Keuangan Perusahaan. Thesis. Fakultas Ekonomi Universitas Sumtera Utara.

Suci, Y. F. 2013. Pengaruh Penerapan Prinsip Good Corporate Governance Terhadap Kinerja Perusahaan pada PT. Kereta Api (Persero) Divisi Regional III Sumatera Selatan.

Sudiyatno, B., dan Suroso, J. 2010. Analisis Pengaruh Dana Pihak Ketiga, BOPO, CAR dan LDR Terhadap Kinerja Keuangan pada Sektor Perbankan yang Go Public di Bursa Efek Indonesia (BEI) (Periode 2005-2008). Dinamika Keuangan Dan Perbankan, 2(2).

Triyana, Y. 2012. Manfaat Penerapan Prinsip-Prinsip Good Corporate Governance Terhadap Kinerja Keuangan Perusahaan Umum Pegadaian.

Weston, J. Fred dan Thomas, Copeland. 2008. "Dasar-dasar Manajemen Keuangan”. Binarupa Aksara. Jakarta

Yazdanfar, D. 2013. Profitability determinants among micro firms: Evidence from swedish data. International Journal of Managerial Finance, 9(2), pp: 151160. 